\title{
Climate Change ${ }^{3}$ !
}

\author{
Arthur M. Michalek ${ }^{1}$
}

Published online: 1 April 2017

(C) American Association for Cancer Education 2017

Greetings from Buffalo, New York, which has been called, among other things, the snow capital of the USA, an unfair reputation earned as a result of a few untimely blizzards. Well, this has been one winter for the books. I reside just south of the city on a house perched atop a low escarpment overlooking Lake Erie. In years past, we have been able to watch snow storms amass over the lake and dump foot upon foot of whiteness upon our lawn. In fact, 2 years ago, we received $7 \mathrm{ft}$ of snow over a 3-day period. Lake Erie historically freezes over in the month of January. This year Lake Erie never froze, we experienced few storms, and none that came even close to paralyzing. It has been such a modest winter that I have been able to ride my bike every month. Is this due to climate change? According to the NOAA [1], "Climate change is a long-term shift in the statistics of the weather...a change in climate normal for a given place and time of year, from one decade to the next... The last decade of the 20th Century and the beginning of the 21 st have been the warmest period in the entire global instrumental temperature record, starting in the mid-19th century." While this may allow me to ride my bike throughout the year, it is not entirely good news. Climate change may lead to very unstable weather patterns producing severe storms such as hurricanes and blizzards, as well as increased sea levels resulting in flooding coastal cities (not to mention the 75-mph wind gusts we recently experienced). This should not be a startling revelation to you. According to a search I conducted of the Web of Science, nearly 27,000 journal articles were published in this area in 2016 alone. Despite overwhelming scientific data and support from much of the

Arthur M. Michalek

amm3@buffalo.edu

1 University at Buffalo, Buffalo, NY, USA scientific community, some members of society remain skeptics. Some claim it to be a hoax, an international conspiracy, a contrivance of the political left, etc. Why is there such divergent opinion on an issue where the evidence appears rather clear? Perhaps some argue against it in fear that such an admission might cause them to change. Some argue just because they have an inherent distrust of experts. Perhaps the major reason is a low level of scientific literacy. Science and mathematics are not emphasized enough within our educational system. Individuals prefer to laugh off their lack of aptitude in these areas and argue that their deficiencies are more than made up for their abilities in other areas. Science they declare "is too complicated". Well, if there is difficulty in educating the public about climate change, what hope do we have when it comes to health care reform or biomedical research?

There is not only a storm in Washington, D.C., over climate change but also with the GOP plans to repeal and replace the Affordable Care Act (ACA) as well as with the president's budget. While the ACA was not a panacea, it certainly was a great start and created a strong foundation upon which other reforms may have been built. Pres. Obama should be lauded for shepherding through such a revolutionary program. As of this writing, the GOP house has repealed the individual mandate and has cobbled together a poorly designed plan with little bipartisan discussion and no real public input. As I pen these final paragraphs, the GOP Health Care Act failed to garner enough support to even reach a House vote. It looks like this storm system has passed, but given the political climate change, I am certain that it will come roaring back with a vengeance. We must be alert. Concerning the recently deceased Act, the American Medical Association, the American Hospital Association, and AARP have voiced their opposition to this early attempt at "reform." Early signs indicate a major victory for health insurance companies. The most recent bill (as of March 9, 2017) restored insurance 
companies' tax deductions for executive salaries above $\$ 500,000$, allowed companies to charge higher premiums for individuals who have not had insurance for 2 months, charged older individuals five times what is charged younger individuals, etc. According to an article in the NYTimes [2], "The congressional Joint Committee on Taxation issued estimates this week showing how much revenue the government could lose starting in 2018 under the Republican bill, which the party has called the American Health Care Act, as a result of repealing taxes on drug makers (nearly $\$ 25$ billion over 10 years), insurers (nearly $\$ 145$ billion), makers of medical devices (nearly $\$ 20$ billion), and high-income households (more than \$270 billion from taxes on earned income and investment income)." The removal of the individual mandate will likely lead to a greater number of uninsured among those most in need of coverage. If a future health care bill goes forward similar to the March 2017 draft, we will quickly return to a past where health care costs are a major cause of personal bankruptcy. Of course, per one prominent GOP senator, individuals will need to decide whether they need health insurance or a new iPhone. With that sort of logic, we are in for one major storm. Keep your eyes peeled and be prepared to batten the hatches!

As of this writing, another storm has appeared on the horizon, the president's budget. President Trump proposes draconian cuts to multiple federal agencies while increasing budgets for defense and national security. While I will not argue against our country's national security, I do take exception to abandoning all the significant gains we have made through medical research and education. Proposed reductions of $18 \%$ to the National Institutes of Health will be devastating to future advancements in medical research. The ripple effect of these cuts will impact our ability to provide state-of-the-art medical care for years to come.
The community in which you live is likely very similar to Buffalo when it comes to dealing with catastrophe. Whether one has experienced a blizzard, tornado, hurricane, mudslide, etc., what quickly becomes evident is how affected communities rally. Perfect strangers come to the aid of others and provide those resources required to recover from the effects of the storm. May we similarly deal with the crises facing health care and medical research/education. May we come together to offer each other support and to rally to the aid of future generations. As Winston Churchill once said, "To build may have to be the slow and laborious task of years. To destroy can be the thoughtless act of a single day." Be ever vigilant and may we remain committed to a slow and laborious task!

On a sad note, I would like to take this opportunity to inform you of the passing of a long time AACE member, past recipient of the Margaret Hay Edwards award, and a stalwart in the cancer education community...Dr. Edwin A Mirand (March 1, 2017; 90 years old). I worked with him for many years at the Roswell Park Cancer Institute on innumerable programs ranging from summer research experiences, graduate education, and community outreach. May he rest in peace.

Be well.

Arthur M. Michalek, PhD, FACE

\section{References}

1. NOAA. http://www.nws.noaa.gov/om/brochures/climate/ Climatechange.pdf

2. Abby Goodnough, Robert Pear, Thomas Kaplan. Health groups denounce G.O.P. bill as its backers scramble. NY Times, March 8, 2017. 